\title{
The Synergy of Paper-Based and Digital Material for Ubiquitous Foreign Language Learners
}

\author{
Sabrina Leone* \\ Faculty of Engineering \\ Università Politecnica delle Marche \\ via Brecce Bianche, 60131 Ancona, Italy \\ E-mail: s.leone@univpm.it

\section{Tommaso Leo} \\ Faculty of Engineering \\ Università Politecnica delle Marche \\ via Brecce Bianche, 60131 Ancona, Italy \\ E-mail: tommaso.leo@univpm.it
}

*Corresponding author

\begin{abstract}
In recent years, the development of digital information transfer, storage and communication methods has allowed for access to ubiquitous global connections and to a large number of resources available to foreign language students at all age and levels of schooling. Further, the combination of traditional paper-based learning material with digital one in a ubiquitous learning environment may offer great innovation in the delivery of education, to foster a student-centred approach, and to accommodate the needs of ubiquitous learners' personal lifestyles. In this direction, research has increasingly emphasised the importance of a technology-enhanced rather than technology-driven learning approach. This paper aims to evaluate the effectiveness of the integration of paper-based and digital material through Quick Response (QR) code for ubiquitous English language learners in three different scenarios. Results show that, despite some difficulties, flexibility and personalisation of learning have been perceived as an asset.
\end{abstract}

Keywords: Ubiquitous Learning; Mobile Learning; Lifelong Learning; Foreign Language Learning; Quick Response Code

Biographical notes: Sabrina Leone is a $\mathrm{PhD}$ student in e-Learning. Her research interests are in lifelong learning, e-Learning, adaptive learning environments and PLE. She has studied and worked (education - teacher and consultant -, business consultancy and linguistic mediation) in Italy and abroad. She has degrees in Foreign Languages, Business Management and Sciences of Linguistic Mediation. She authored and co-authored 10 publications on referred journals and books.

Tommaso Leo is currently Full Professor, Chair Automatic Control at the Università Politecnica delle Marche of Ancona. Rector delegate to e-Learning at UnivPM, Coordinator of the PhD Course in e-Learning. Director of DIIGA UnivPM- Italy. Chair of Research Programs in Robotics, Automation, Human Movement Analysis and e-learning. Author and co-author of more than 220 scientific papers. Scientific Coordinator of a number of EU funded Projects and Partner in national projects. 


\section{Mobile Learning vs. Ubiquitous Learning}

The affordances of new technologies in education are enabling the development of wireless learning environments that facilitate students' participation and interaction, and the creation of platforms which support ubiquitous students' learning styles and goals. All over the world wireless technologies are taking over from wired technologies and there is an inevitable movement towards mobile learning (m-Learning) and ubiquitous learning (u-Learning).

M-Learning and u-Learning are similar concepts and are often used as synonyms in research literature (Kukulska-Hulme, Sharples, Milrad, Arnedillo-Sánchez, \& Vavoula, 2009). Anyhow, this study refers to m-Learning as the provision of education and training on PDAs (Personal Digital Assistants), palmtops, handheld devices, smartphones and mobile phones (Keegan, 2004; Nix, 2005), and to u-Learning as a new information and communication technology that exploits a large number of cooperative small nodes with computing and/or communication capabilities, such as handheld terminals, smartphones, sensor network nodes, contact-less smart cards, RFID (Radio Frequency Identification) (El-Bishouty, Ogata \& Yano, 2007) and QR codes.

M-Learning is characterised by high mobility and low embeddedness: data storage and communication are easy, learning is enabled at anytime and anyplace through mobile phones, ipods, NintendoDS. Issues are that learning at anytime and anyplace is not enough and that personalisation according to the learner's context is also important to provide the appropriate learning contents and to enhance learning in the real world.

The shift from m-Learning to u-Learning takes place through three steps: (1) mLearning is adopted inside classroom settings; (2) m-Learning is adopted outside classroom settings; (3) u-Learning is adopted inside/outside the classroom with embedded devices.

U-Learning is characterised by high mobility, using PDA, smartphones, mobile phones and ultra-mobile PCs, and high embeddedness, using means such as RFID, sensor networks and QR codes. Mobile devices work in cooperation with embedded devices through wired/wireless communication.

On these bases, beyond providing anytime-anywhere information, the challenge of future computer systems consists in transferring the right thing at the right time in the right way to the right person (El-Bishouty, Ogata, \& Yano, 2007). Ubiquitous computing diffusion has lately been accelerated by improved wireless telecommunications, open networks, continuous increasing in computing power, improved battery technology, the emergence of flexible software architectures, cheaper handheld devices. Thanks to this technological growth, an individual learning environment could be embedded in everyday life (Ogata \& Yano, 2004) and mobile devices are now being introduced as learning devices.

A Computer Supported Ubiquitous Learning (CSUL) environment, that was coined for everyday learning with the support of ubiquitous computing technologies, shows the following features (Chen, Kao, Sheu, \& Chiang, 2002; Curtis, Luchini, Bobrowsky, Quintana, \& Soloway, 2002):

- $\quad$ permanency - all the learning processes are recorded continuously in everyday life; 
- accessibility - learners have access to their documents, data, or videos from anywhere;

- $\quad$ immediacy - wherever learners are, they can get any information immediately;

- interactivity - learners can interact with experts, teachers, or peers in synchronous and/or asynchronous communication at anytime and anyplace;

- situated-ness - both the problems arising and the knowledge required in individuals' daily life are "situated", i.e. presented in authentic forms and contexts, and therefore, they are easily focussed;

- adaptability - according to the learner's situation, the system should provide the right information at the right time, in the right place, in the right way, to the right person.

Learning theories for CSUL are authentic learning (Brown, Collins \& Duguid, 1989), situated learning (Lave \& Wenger, 1991) and learning by doing (Schank, 1995).

\section{Ubiquitous Learners' Features and Learning Goals}

U-Learning affordances and CSUL features let ubiquitous learners (u-Learners) become lifelong learners (LLLearners). LLLearners are characterized as demonstrating perseverance, initiative, and adaptive abilities. LLLearners are self-regulated learners, that is they are equipped to direct their own learning and development, and are proactive in gaining access to and accomplishing learning (Leone, 2010). LLLearners:

- have a novice's approach, rather than an expert's attitude, that let them take advantage of all learning opportunities;

- relate and exploit the knowledge and the competences they have acquired in other contexts;

- $\quad$ are flexible and adaptable to favour learning;

- are always fond of learning something for the pleasure of acquiring and for personal empowerment;

- $\quad$ are curious and feed their curiosity;

- learn in many ways;

- teach others to improve their competence.

In this view individuals should wonder if they are developing the necessary skills to be competitive in the 21st century: global and active citizenship, flexibility, innovativeness, problem solving, information literacy, critical thinking, cooperative learning, self-learning, lifelong learning (LLL), global awareness, knowledge management and sharing. This long list can be summed up in one of the basic skills for success in the knowledge society, i.e. the ability to learn. Learning to learn is strictly linked to the concept of "effective learning". Educational and psychology researchers have mused for decades on what features make up "effective learning".

Technology undoubtedly improves the learning experience, makes it more authentic, facilitates the transfer of skills from the classroom to the workplace. Still, the focus can't be on technology, but on learning. The benefits arising from the introduction of ICTs in the learning curriculum have to be assessed within the learning experience, the usefulness of learning and its enhancements (Leone, 2008). As a result, in terms of creating an effective learning environment, five aspects appear as being vital (Agostinho, Lefoe, \& Hedberg, 1997): 
- offering opportunities to encourage personal construction of knowledge; by

- creating a suitable context for the learning; by

- defining a meaningful (to the learner) purpose for collaboration; and by

- facilitating collaboration amongst learners; through the use of

- conversation and text-based communication.

According to recent literature (Bulu \& Yildirim, 2008; Calvani, 2006; Ellis, 1999; Wasson, 2007), social interaction among learners is a major element of the learning process, indeed, it can decisively impact on learning outcomes (Agostinho, Lefoe, \& Hedberg, 1997). A new theoretical interpretation of teaching and learning methods (Barr \& Tagg, 1995; Calvani, 2006; Jonassen \& Land, 2000; Riischoff \& Ritter, 2001; Varisco, 2002) is needed to support the new educational models that are being introduced in the light of the technology-enhanced learning paradigm:

- flexible delivery (multiple options for scheduling, location and modes of learning);

- increasing self-directed learning, to meet individual learning goals and needs;

- the shift from a transmissive approach, teacher-centred and top-down one, to a constructivist approach, learner-centred, bottom-up one;

- the teacher acting as a facilitator, providing a well-designed learning environment to foster active and cooperative learning experiences.

Accordingly, a learning environment that incorporates mobile devices should offer u-Learners (Nalder, 2008):

- active learning models that facilitate rich, collaborative instruction;

- expansion of previous understandings of spatial/classroom boundaries and the possibilities that active learning with mobile technology might provide, such as enhancing existing learning within individual contexts, recording or creating data anywhere, listening and viewing educational material anywhere, carrying and managing learning tasks and associated files everywhere;

- cheaper handheld, non-wireless devices for simpler learning goals, handheld devices with communication abilities for tasks requiring collaboration and connectivity, more capable devices such as laptops for higher order tasks. u-Learners to:

Finally, a learning environment that integrates wireless technology should allow

- cultivate a culture of learning conversations, where individuals collaborate and communicate anytime;

- learn filtering and managing conversations and information;

- become familiar with appropriate and ethical uses of anywhere connectivity;

- become familiar with operational wireless options that fit the learning vision, such as setting up specific wireless learning zones, setting up campus-wide wireless access, allowing for long-range wireless connectivity outside of traditional school hours. 


\section{The Integration of Paper-Based and Digital Material for Foreign Language Learning}

In Europe in the last two decades the implementation of ICT in education has had a positive impact both on foreign languages teachers' and learners' attitudes, as a consequence of the major changes in teaching and learning theories and methodologies (Leone, Leo, \& Chen, 2010). In this field, Computer-Assisted Language Learning (CALL) (Levy, 1997) and Web-Based Training (WBT) represent the two most recurrent and central research areas of present times. In addition, a new perspective related to technology and language learning known as Integrative CALL allows technology to be fully incorporated in the process and gives the student the possibility of using a great variety of technological tools and resources (Warschauer, 1996; Leone, Leo, \& Chen, 2010).

WBT offers live content in a layout allowing self-directed and self-paced instruction in any topic. WBT is a media-rich, flexible vehicle for delivering training to individuals anywhere in the world at any time. The recent focus of WBT development is on learning how to use the available tools and organize content into effective learning systems (Agostinho, Lefoe, \& Hedberg, 1997). Consistently, socio-cognitive approaches have enhanced the use of language in authentic social contexts: offering students contemporary, up-to-date learning experiences and authentic material is a current challenge for language educators. Further, interaction and conversation are central in the communicative approach to language learning (Pachler, 2002). Finally, the development of the four language learning skills through task-based, project-based and content-based methodologies has aimed at the learner's integration within real learning environments. The four language learning skills are listening and reading (comprehension, passive skills), and speaking and writing (production, active skills). Reading involves printed material. Paper and traditional books have been serving as useful tools in supporting knowledge-intensive tasks and learning (Chao \& Chen, 2009). However, a paper textbook can be complemented with mobile technologies and the combination can be considered as a whole to enhance reading comprehension and to enrich it with audio, video and grammar, vocabulary and cultural in-depth contents.

Paper-based learning material has shown to have been successfully enhanced by multimedia contents in experiences on annotation carried out through digital pen (Chao \& Chen, 2009; Lai, Chao, \& Chen, 2007). Little literature (Chen, Teng, \& Lee, 2010) is available about the principles of instructed language learning in the use of paper-based learning material integrated with digital material through QR code and about its potentials as ubiquitous learners' tools.

The advantage of QR code if compared to a normal bar code, where information is presented exclusively in a horizontal direction, is the ability to display information in both vertical and horizontal directions (Savarani \& Clayton, 2009). This allows learners greater amounts of information and services (such as website addresses, text and numerical information, and contact details) to be stored within the code and to be readily accessed (Ramsden, 2009). The information contained in the QR code is decoded by a smartphone with an embedded camera and code reading software installed. Embedding QR codes into paper-based learning material enables u-Learners to move from place to place, and to use readily-available, handheld computing devices and communication technology to access information and learning materials from anywhere and at anytime. Besides fostering flexibility of provision, the integration of $\mathrm{QR}$ codes with paper-based learning material also offers the personalisation of learning because different learning styles and approaches to the use of ICT for learning can be accommodated. Finally, the 
main benefits of QR code are: (1) no cost, (2) ease of use, (3) mobility/portability, (4) access anytime, (5) instant gratification. On the other hand, main issues of the adoption of QR codes in learning could be: (1) mobile Internet too slow, (2) mobile Internet too expensive, (3) software, (4) identical twins, (5) lighting, (6) complicated process.

In this scenario, the advances of mobile technology make mobile phone a basic tool for social communication, work, learning and leisure activities. Also, the lower cost of mobile phones makes it more affordable and accessible to a wider range of population. In the end, portability and mobility are consistent to those of paper-based reading, that makes mobile phone one of the most appropriate devices to be used in this application, but not the only one.

\section{Case Studies: Design and Implementation}

The case studies which follow describe an experience of integration of paper-based and digital learning material through QR code within three courses of English as a foreign language (EFL) that one of the authors held in three different scenarios, from February to June 2010: a refresher course for Italian secondary school teachers (23 participants, 10 weekly 3-hour lectures), a language certification course for Italian secondary school students (upper classes, 16 participants, 17 3-hour lectures twice a week) and a course for Italian adult beginners (15 participants, 20 weekly 3 -hour lectures). Participants were 54 in all. Since the institutions that organised the courses provided workstations but no mobile devices, 39 students used their own (laptops or ultra-mobile PCs or smartphones, with a video camera and a QR code reader) to participate in the activities proposed through QR code as in-depth learning contents; all the others carried out this work exploiting hardcopies only.

All the courses were carried out over three F2F modules, (1) "Introducing oneself and others", (3) "Hobbies and places", (4) "Everyday life", and an experimental module in u-Learning, (2) "Meeting people". Personalisation was provided through a great variety of graded learning materials, by interactive and self-assessment web-based activities, and by proposing the u-Learning module "Meeting people" in hard copy and pdf file, both integrated with in-depth digital contents in QR codes. The contents included inherent communicative functions, grammar and vocabulary and paper-based and QR code activities, as described in table 1 .

Figures 1 and 2 respectively are an extract of the integrated activities proposed for the communicative function "Asking for and giving information and direction" and a view of those captured in $\mathrm{QR}$ code. skills:

The learners carried out the following activities in relation to the four language

- Listening: listening comprehension (with and then without script) of dialogues about real-life situations by true/false, multiple choice and cloze activities, and open questions; listen and repeat, listen and speak, and listen, speak and record correct sentences;

- Reading: reading comprehension of dialogues, short stories, descriptions and letters/emails about real-life situations by true/false, multiple choice and cloze activities, and open questions; 
Table 1. Contents of the u-Learning module "Meeting people"

\begin{tabular}{|c|c|c|c|c|}
\hline $\begin{array}{l}\text { Communicative } \\
\text { functions }\end{array}$ & Grammar & Vocabulary & $\begin{array}{l}\text { Paper-based } \\
\text { activity }\end{array}$ & QR Code activity \\
\hline $\begin{array}{l}\text { Likes and } \\
\text { dislikes. }\end{array}$ & $\begin{array}{l}\text { Present } \\
\text { simple; } \\
\text { prepositions of } \\
\text { time; }\end{array}$ & $\begin{array}{l}\text { Food; leisure } \\
\text { activities. }\end{array}$ & $\begin{array}{l}\text { Put a tick on the } \\
\text { table of sports, } \\
\text { drinks and food } \\
\text { you like and } \\
\text { report results to } \\
\text { your partner. }\end{array}$ & $\begin{array}{l}\text { 1. Watch the video } \\
\text { "Hot sands" and } \\
\text { complete the } \\
\text { sentences (multiple } \\
\text { choice); } \\
\text { 2. watch the video } \\
\text { and answer the } \\
\text { questions. }\end{array}$ \\
\hline $\begin{array}{l}\text { Talking about } \\
\text { activities and } \\
\text { abilities. }\end{array}$ & $\begin{array}{l}\text { modal verb } \\
\text { can; } \\
\text { the -ing form; }\end{array}$ & $\begin{array}{l}\text { Jobs and } \\
\text { skills; leisure } \\
\text { activities. }\end{array}$ & $\begin{array}{l}\text { Read this article } \\
\text { and complete it } \\
\text { with the correct } \\
\text { form of the } \\
\text { verbs. }\end{array}$ & $\begin{array}{l}\text { 1. Watch and } \\
\text { complete with the } \\
\text { simple present; } \\
\text { 2. watch the video on } \\
\text { can and could and } \\
\text { answer the } \\
\text { questions. }\end{array}$ \\
\hline $\begin{array}{l}\text { Talking about } \\
\text { time }\end{array}$ & $\begin{array}{l}\text { Prepositions } \\
\text { of time. }\end{array}$ & Numbers. & $\begin{array}{l}\text { Say the time of } \\
\text { your everyday } \\
\text { activities. }\end{array}$ & $\begin{array}{l}\text { Listen to the times, } \\
\text { match and repeat. }\end{array}$ \\
\hline $\begin{array}{l}\text { Talking about } \\
\text { hobbies and } \\
\text { interest }\end{array}$ & Let's... & $\begin{array}{l}\text { Leisure } \\
\text { activities. }\end{array}$ & $\begin{array}{l}\text { Number the } \\
\text { sentences to } \\
\text { make a dialogue. }\end{array}$ & $\begin{array}{l}\text { Watch the pictures } \\
\text { and record the correct } \\
\text { sentence. }\end{array}$ \\
\hline $\begin{array}{l}\text { Describing a } \\
\text { room }\end{array}$ & $\begin{array}{l}\text { Prepositions } \\
\text { of place; } \\
\text { there is/are + } \\
\text { any, a; } \\
\text { question } \\
\text { words } \\
\text { (what...like?); } \\
\text { plural nouns. }\end{array}$ & $\begin{array}{l}\text { Objects in a } \\
\text { room; } \\
\text { places. }\end{array}$ & $\begin{array}{l}\text { 1. Match objects } \\
\text { in the house } \\
\text { in the picture; } \\
\text { 2. complete with } \\
\text { prepositions }\end{array}$ & $\begin{array}{l}\text { In-depth grammar: } \\
\text { revise prepositions of } \\
\text { place. }\end{array}$ \\
\hline $\begin{array}{l}\text { Describing and } \\
\text { locating places }\end{array}$ & “ & Places. & $\begin{array}{l}\text { Read the passage } \\
\text { and say if the } \\
\text { following } \\
\text { statements are } \\
\text { true or false. }\end{array}$ & $\begin{array}{l}\text { 1. Listen to the } \\
\text { passage; } \\
\text { 2. reading: types of } \\
\text { houses. }\end{array}$ \\
\hline $\begin{array}{l}\text { Asking for and } \\
\text { giving } \\
\text { information and } \\
\text { direction }\end{array}$ & “ & Places. & $\begin{array}{l}\text { Look at the map } \\
\text { and in pairs ask } \\
\text { for/give } \\
\text { directions to } \\
\text { reach the } \\
\text { following } \\
\text { places.. }\end{array}$ & $\begin{array}{l}\text { 1. Complete } \\
\text { dialogues; } \\
\text { 2. Watch the video on } \\
\text { directions and } \\
\text { answer the } \\
\text { questions. }\end{array}$ \\
\hline
\end{tabular}


- Writing: beside all the activities described above for listening and reading comprehension, reordering the sentences in a dialogue, completion with grammar elements, short stories about oneself, short summaries, descriptions, letters/emails;

- Speaking: repetition of parts of a dialogue (listen and repeat), role-play of a dialogue (gradually proposed as structured, semi-structured and unstructured), descriptions, stories about oneself.

Giving directions

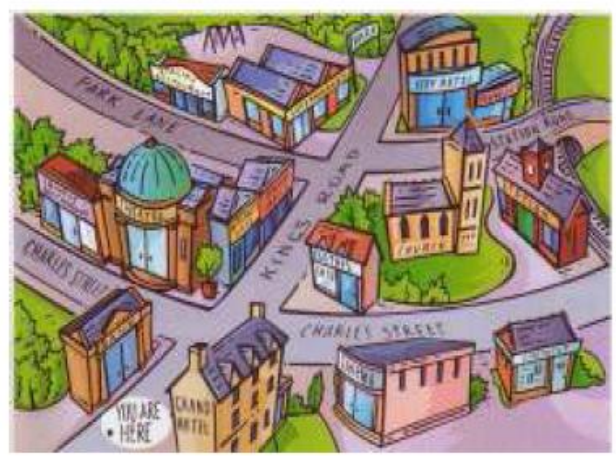

Activity 1

Work with a partner. Make dialogues as in the following example. You want to go to...

- a cinema

- a pos. office

- a neusagent

- a superrmarlet

- a theitre

- an ltaliat restaurant

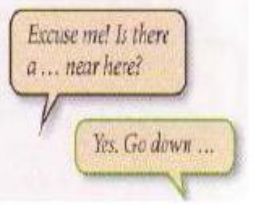

Activity 2

Complete the dialogue

(units 3-4, ex.4)

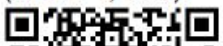

Activity 3

Watch the video about Directions and answer the questions.

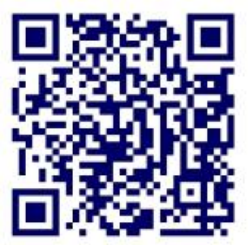

Figure 1. Extract of the integrated activities in "Asking for and giving information and direction"

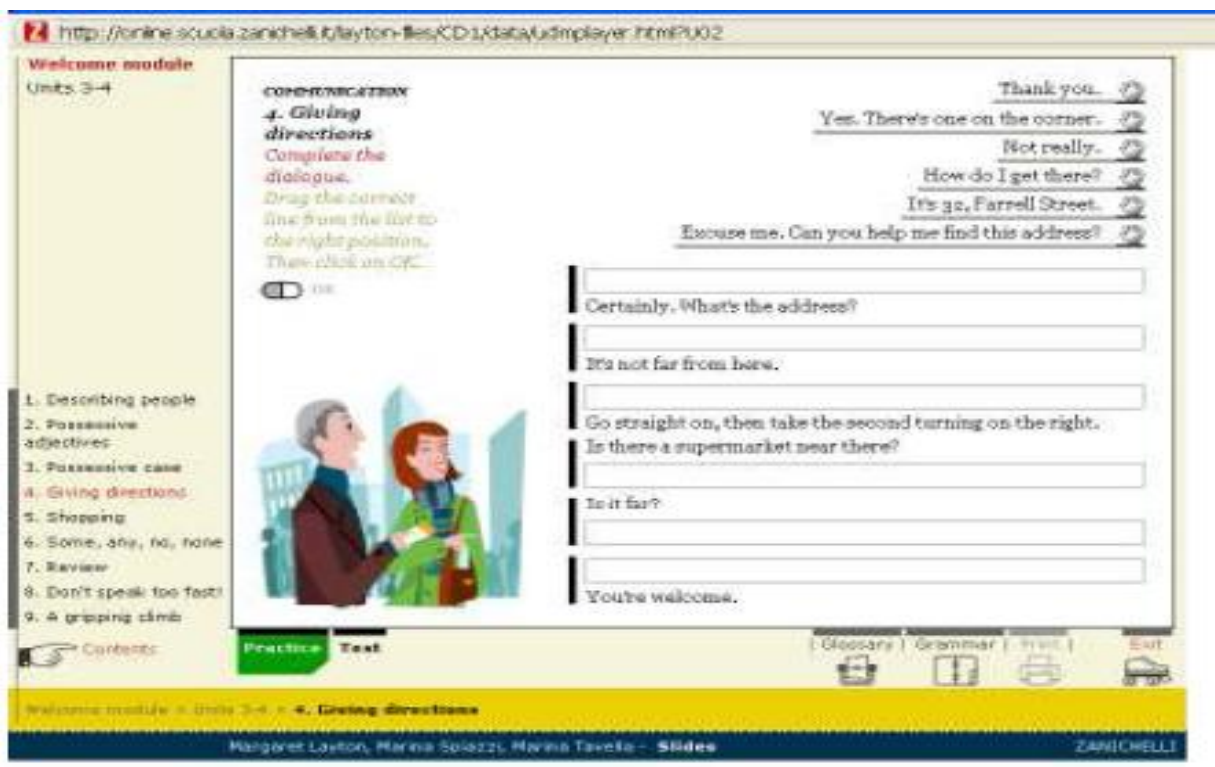




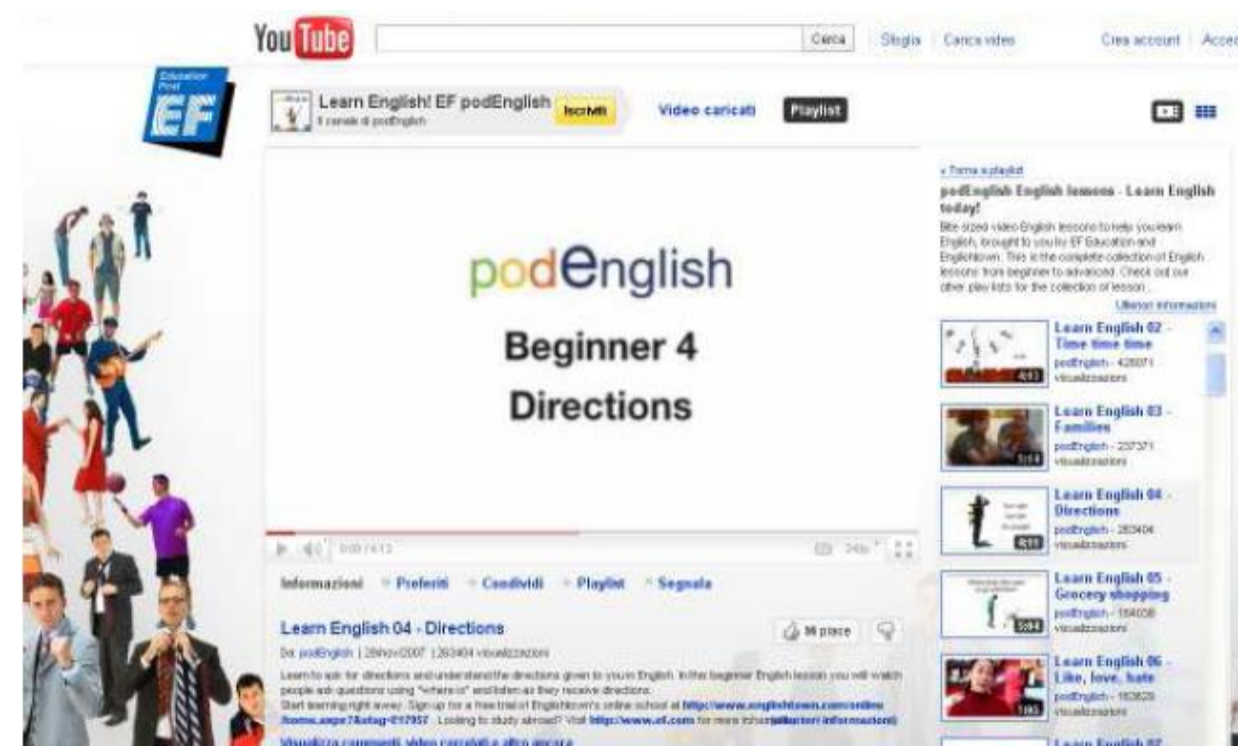

Figure 2. View of activities 2 and 3 (fig. 1) captured in QR code

The teacher's aim was to go along with the participants' learning styles and needs, and to let them use their favourite format (hard copy or pdf file) and media. For this reason, the in-depth materials captured in QR codes included situationed videos, pictures, audio (dialogues) podcasts, short texts and grammar and vocabulary tables, among which learners could choose and be at ease, with the teacher's support during classes, and, in or out of classes, with the help of guidelines for the gradation of the selected learning material and of self-check tests. The teacher suggested the learners to complete selfcheck test forms before and after working on each communicative function. As table 2 shows, each form contained sections, items and self-assessment columns; at the bottom, a "suggested learning path" area is provided on the basis of the score students marked.

Table 2. Example of self-check test for the communicative function "Likes and dislikes"

\begin{tabular}{|c|l|l|l|l|}
\hline Sections & \multicolumn{1}{|c|}{ Items } & Easy & \multicolumn{1}{|c|}{$\begin{array}{c}\text { Quite } \\
\text { difficult }\end{array}$} & $\begin{array}{c}\text { I need more } \\
\text { practice }\end{array}$ \\
\hline \multirow{3}{*}{ Knowledge } & $\begin{array}{l}\text { Communicative function: } \\
\text { Likes and dislikes. }\end{array}$ & & \\
\cline { 2 - 5 } & $\begin{array}{l}\text { Grammar - complete the spaces: } \\
\text { What music...you like? } \\
\ldots \ldots \text { you like Italian food? } \\
\text { Mary.... water to wine. } \\
\text { I.....horror films; I'm scared. }\end{array}$ & & \\
\cline { 2 - 5 } & $\begin{array}{l}\text { Vocabulary: } \\
\text { Food } \\
\text { Leisure activities }\end{array}$ & & \\
\hline \multirow{3}{*}{ Skills } & $\begin{array}{l}\text { Listening comprehension: } \\
\text { I can understand people talking about } \\
\text { their hobbies. } \\
\text { I can understand questions about my } \\
\text { favourite things. }\end{array}$ & & & \\
& & & \\
& & & \\
\hline
\end{tabular}




\begin{tabular}{|c|c|c|c|c|}
\hline & $\begin{array}{l}\text { Speaking: } \\
\text { I can buy tickets for a football match. } \\
\text { I can express my likes and dislikes. }\end{array}$ & & & \\
\hline & $\begin{array}{l}\text { Reading comprehension: } \\
\text { I can read and understand a home page } \\
\text { about leisure activities. } \\
\text { I can read and understand a datafile. }\end{array}$ & & & \\
\hline & $\begin{array}{l}\text { Writing: } \\
\text { I can write a letter about myself. } \\
\text { I can write a short description of my } \\
\text { best friend's likes and dislikes. }\end{array}$ & & & \\
\hline \multicolumn{5}{|c|}{ Score (total number of ticks for each column). } \\
\hline \multicolumn{2}{|c|}{ Suggested learning path } & $\begin{array}{l}\text { Go to } \\
\text { the } \\
\text { next } \\
\text { unit. }\end{array}$ & $\begin{array}{l}\text { Use } \\
\text { activities } \\
\text { at p. } 27 \\
\text { to revise } \\
\text { the } \\
\text { difficult } \\
\text { items. }\end{array}$ & $\begin{array}{l}\text { Use } \\
\text { activities at } \\
\text { p. } 27-29 \text { to } \\
\text { practice } \\
\text { more the } \\
\text { items } \\
\text { indicated. }\end{array}$ \\
\hline
\end{tabular}

Objectives of the "paper $+Q R$ code" experimentation were facilitating flexibility and personalisation of the learning module, and producing effective learning by providing the participants with multifaceted and multimedia learning materials, suitable for the learning styles and goals that emerged from the entry test (a multiple-choice survey, with more possible answers). Learning styles were determined on the model of Felder and Silverman (1988), through the Felder and Soloman's Index of Learning Styles Questionnaire $^{l}$, within the four segments active-reflective, sensing-intuitive, visualverbal and sequential-global learners. The participants resulted in being made up of 40.7\% moderately active learners, $9.2 \%$ moderately sensing learners, $37 \%$ moderately visual learners and $14.8 \%$ moderately global learners. As a whole, participants' learning goals showed to be learning English to communicate with a different culture (72\%) and improve personal background (82\%). In addition, $33 \%$ of the learners affirmed that they would spend some months studying, working or living in an English-speaking country and that their necessary know-how would be made of basic communicative and language competences (92\%) and the knowledge of traditions and values in a vision of cultural relativism (41\%). Accordingly, participants expected the course to give them situated and effective knowledge (54\%), "spendable" skills (70\%), technology-enhanced (79\%) and personalised learning (28\%). Only $11 \%$ of the respondents had already learnt with ICT and none with mobile technologies different from laptops; in particular 56\% had used a multimedia laboratory and mainly email (55\%) to interact; a few had used forums $(12 \%)$, blogs $(16 \%)$ and social networks (12\%). The difficulties that respondents had experienced while learning language with ICT were distributed among language comprehension $(27 \%)$, poor connection $(20 \%)$, a lot of time to get familiar with the learning environment (20\%) and difficult orientation with the learning material $(18 \%)$. Despite their evident preference for technology-enhanced learning, respondents stressed that collaborative work is easier face-to-face (F2F) $(67 \%)$ rather than in blended courses (29\%). $93 \%$ of the respondents declared to have a computer at home, $45 \%$ an ADSL connection and $90 \%$ are able to use them. In relation to mobile technologies, all of the

\footnotetext{
${ }^{1}$ Available at http://www.engr.ncsu.edu/learningstyles/ilsweb.html
} 
participants declared to have a mobile phone, but only $7 \%$ a PDA and $7 \%$ a smartphone; $66 \%$ have a laptop, $27 \%$ a game console and $11 \%$ an ultra-mobile PC. $56 \%$ affirmed to be ready for u-Learning as a fundamental means for LLL (66\%). Even though $76 \%$ of the respondents use mainly the basic functions of a mobile phone (phone calls, SMS, MMS), $34 \%$ have lately used mobile phone to learn ( $16 \%$ by bluetooth and $5 \%$ by GPS; $7 \%$ surf the Net by phone card and $7 \%$ in wireless). The learning tools participants use are audio/video podcasts (23\%), Mp3 (19\%), Instant Messaging (5\%) and Skype (5\%); none had ever used QR code. In the respondents' view, the drawbacks of u-Learning are the time to get familiar with it (71\%), impersonal learning $(17 \%)$, the need for greater selfdiscipline $(11 \%)$ and the need for a high technological know-how $(7 \%)$. On the other hand, $\mathrm{u}$-Learning offers independence from time and place $(65 \%)$, flexible contents $(30 \%)$ and personalised learning (33\%). Finally, respondents highlighted that expected improvements to facilitate u-Learning could be expanded mobile phones' memory (98\%), cheaper connection charges $(93 \%)$, faster data transmission $(91 \%)$, unified technology $(72 \%)$ and larger displays of mobile phones (57\%). Table 3 reports the most representative figures for the three different scenarios (in bold all the figures mentioned above).

Table 3a. Summary of entry test outcomes for the three scenarios (questions 1-4)

\begin{tabular}{|c|c|c|c|c|}
\hline Scenario & 1 & 2 & 3 & $\begin{array}{l}\text { Average } \\
\text { results }\end{array}$ \\
\hline Title of the course & English for us & $\begin{array}{l}\text { Trinity for } \\
\text { grades } 6-8\end{array}$ & First steps & - \\
\hline Kind of course & $\begin{array}{l}\text { Refresher } \\
\text { course }\end{array}$ & $\begin{array}{l}\text { Language } \\
\text { certification } \\
\text { course }\end{array}$ & $\begin{array}{l}\text { Vocational } \\
\text { course }\end{array}$ & - \\
\hline Participants & $\begin{array}{l}23 \text { Italian high } \\
\text { school teachers }\end{array}$ & $\begin{array}{l}16 \text { Italian high } \\
\text { school } \\
\text { students } \\
\end{array}$ & 15 Italian adults & - \\
\hline Duration & 10 weeks/30h & 17 weeks/50h & 20 weeks/60h & - \\
\hline Language level & beginner & intermediate & beginner & - \\
\hline \multirow[t]{2}{*}{ Objectives } & $\begin{array}{c}\text { A1 } \\
\text { (Breakthrough) } \\
\text { language ability } \\
\text { level }\end{array}$ & $\begin{array}{c}\mathrm{B} 1+2 \\
\text { (Intermediate) } \\
\text { lang. ability } \\
\text { level }\end{array}$ & $\begin{array}{c}\text { A1 } \\
\text { (Breakthrough) } \\
\text { lang. ability } \\
\text { level }\end{array}$ & - \\
\hline & \multicolumn{4}{|c|}{$\begin{array}{l}\text { personalised learning through flexible and gradable tools and } \\
\text { materials }\end{array}$} \\
\hline \multicolumn{5}{|l|}{ Questions } \\
\hline $\begin{array}{l}\text { 1. Age: } \\
\text { - } 15-18 \\
\text { - } 36-45 \\
\text { - } 46-55 \\
\end{array}$ & $\begin{array}{r}-- \\
-- \\
64 \%\end{array}$ & $\begin{array}{r}86 \% \\
-- \\
--\end{array}$ & $\begin{array}{r}-- \\
33 \% \\
40 \%\end{array}$ & $\begin{array}{l}29 \% \\
11 \% \\
35 \%\end{array}$ \\
\hline 2. Women & $64 \%$ & $73 \%$ & $67 \%$ & $68 \%$ \\
\hline $\begin{array}{l}\text { 3. } \begin{array}{l}\text { Years of } \\
\text { professional } \\
\text { experience }>10\end{array} \\
\end{array}$ & $84 \%$ & -- & $60 \%$ & -- \\
\hline $\begin{array}{l}\text { 4. I'm an absolute } \\
\text { beginner }\end{array}$ & $60 \%$ & -- & $33 \%$ & $31 \%$ \\
\hline
\end{tabular}


Table 3b. Summary of entry test outcomes for the three scenarios (questions 5-8)

\begin{tabular}{|l|r|r|r|r|}
\hline \multicolumn{1}{|c|}{ Scenario } & 1 & 3 & Average \\
results
\end{tabular}


Table 3c. Summary of entry test outcomes for the three scenarios (questions 9-13)

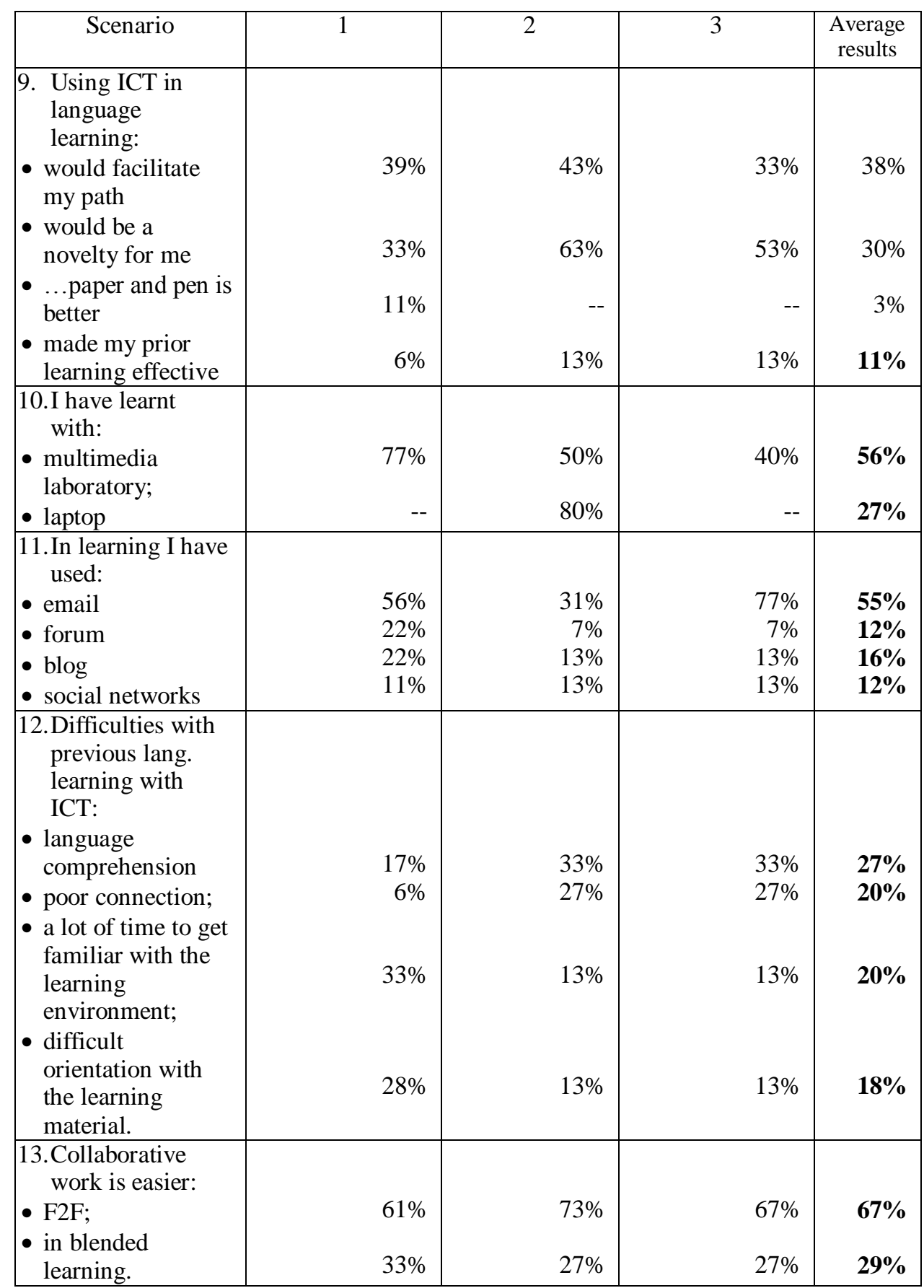


Table 3d. Summary of entry test outcomes for the three scenarios (questions 14-19)

\begin{tabular}{|c|c|c|c|c|}
\hline Scenario & 1 & 2 & 3 & $\begin{array}{l}\text { Average } \\
\text { results }\end{array}$ \\
\hline $\begin{array}{l}\text { 14. At home I have: } \\
\text { - a computer } \\
\text { - an ADSL } \\
\text { connection. } \\
\text { I can use both. }\end{array}$ & $\begin{array}{l}94 \% \\
78 \% \\
78 \%\end{array}$ & $\begin{array}{r}77 \% \\
50 \% \\
100 \%\end{array}$ & $\begin{array}{l}93 \% \\
87 \% \\
93 \%\end{array}$ & $\begin{array}{l}93 \% \\
45 \% \\
90 \%\end{array}$ \\
\hline $\begin{array}{l}\text { 15. Mobile devices I } \\
\text { own and use: } \\
\text { - } \text { PDA/smartph } \\
\text { - mobile phone } \\
\text { - ultra-mobile PC } \\
\text { - laptop } \\
\text { - game console }\end{array}$ & $\begin{array}{r}8.5 \% \\
100 \% \\
13 \% \\
35 \% \\
--\end{array}$ & $\begin{array}{r}12.5 \% \\
100 \% \\
18.8 \% \\
\\
69 \% \\
80 \%\end{array}$ & $\begin{array}{r}20 \% \\
100 \% \\
-- \\
93 \% \\
--\end{array}$ & $\begin{array}{r}14 \% \\
100 \% \\
11 \% \\
66 \% \\
27 \%\end{array}$ \\
\hline $\begin{array}{l}\text { 16.I'm ready for u- } \\
\text { Learning }\end{array}$ & $57 \%$ & $40 \%$ & $70 \%$ & $56 \%$ \\
\hline $\begin{array}{l}\text { 17. U-Learning is } \\
\text { crucial for LLL }\end{array}$ & $69 \%$ & $80 \%$ & $50 \%$ & $66 \%$ \\
\hline $\begin{array}{l}\text { 18.I have lately used } \\
\text { mobile phone to } \\
\text { learn } \\
\text { - by bluetooth } \\
\text { - by GPS } \\
\text { - surfing the Net } \\
\text { by phone card } \\
\text { - in wireless } \\
\text { connection }\end{array}$ & $\begin{array}{r}19 \% \\
-- \\
-- \\
6 \% \\
13 \%\end{array}$ & $\begin{array}{r}42 \% \\
7 \% \\
14 \% \\
14 \% \\
7 \%\end{array}$ & $\begin{array}{r}40 \% \\
40 \% \\
-- \\
-- \\
--\end{array}$ & $\begin{array}{r}34 \% \\
16 \% \\
5 \% \\
7 \% \\
7 \%\end{array}$ \\
\hline $\begin{array}{l}\text { 19. I have lately used } \\
\text { mobile phone to } \\
\text { learn by } \\
\text { - audio/video } \\
\text { podcasts } \\
\text { - Mp3 } \\
\text { - Instant } \\
\text { Messaging } \\
\text { - Skype } \\
\text { - QR code }\end{array}$ & $\begin{array}{l}-- \\
-- \\
--\end{array}$ & $\begin{array}{r}40 \% \\
27 \% \\
14 \% \\
14 \% \\
--\end{array}$ & $\begin{array}{r}30 \% \\
30 \% \\
-- \\
-- \\
--\end{array}$ & $\begin{array}{r}23 \% \\
19 \% \\
5 \% \\
5 \% \\
--\end{array}$ \\
\hline
\end{tabular}


Table 3e. Summary of entry test outcomes for the three scenarios (questions 20-22)

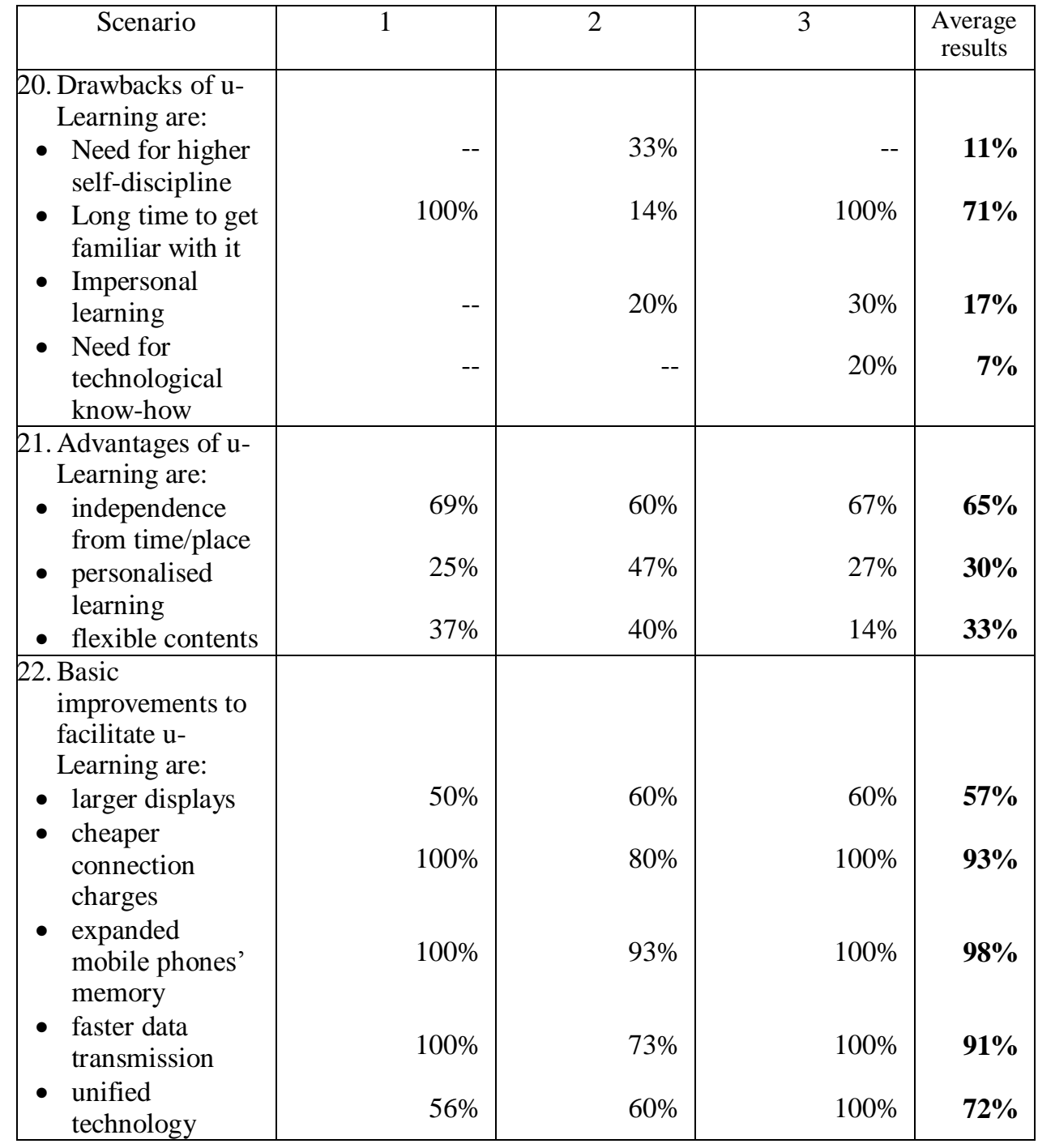

The design of the courses was based on the ADDIE Instructional Design model and rapid e-learning tools (Piskurich, 2006; Savery \& Duffy, 1994). The approach adopted was learner-centred and emphasised motivational factors. Methodology drew on constructivism, socio-constructivism, cooperative learning (peer and group work) (Barr \& Tagg, 1995; Jonassen \& Land, 2000; Riischoff \& Ritter, 2001; Varisco, 2002; von Glasersfeld, 1998), notional-functional syllabus and communicative approach (Nunan, 1991), active (Vygotsky, 1986) and situated learning (Lave \& Wenger, 1991) and learning by doing (Schank, 1995). Scaffolding was used both in F2F and asynchronous communication. Assessment, basically centred on self-assessment (interactive tests) and peer-assessment, consisted of an entry test, that aimed to determine learners learning styles, learners' approach to technology-enhanced learning and learners' language skills; ongoing tests; formative tests, at the end of each module; a summative test, at the end of 
the courses. Assessment parameters were interaction, participation and fluency, for linguistic-communicative skills, and vocabulary and grammar appropriateness, linguisticstructural skills.

In the three scenarios, in week one the teacher introduced the course. Language, cognitive and cross-curriculum objectives, and contents references were illustrated. After the entry test had been delivered and results collected, part of week one was dedicated to the homogenization of the students' ICT knowledge and to the integration of the necessary basics. The u-Learning module was thoroughly explained and carried out starting from week three to week six. Guidelines and support (research, download and installation of QR code decoder software, too) were provided to allow the learners become u-Learners and achieve their language learning goals working independently, collaboratively and cooperatively. The data of the entry test showed that most of the participants appeared open to experience this new way of learning through technologies. Anyhow, some initial technological problems (difficulties in downloading and/or visualizing educational material because of poor Internet connection and slow processors on the participants' mobile devices) affected motivation. This required fast troubleshooting and a thorough and sensitive construction of an emotionally favourable learning environment to reduce learners' affective barriers and support learning, through scaffolding, mediation, focus on achievements and positive reinforcement. In the following, all the planned activities were carried out with different results. As a whole, students were more and more motivated and self-confident and ongoing assessment showed an improvement in their language skills, interaction and participation. In particular, tables 4 and 5 report the results of entry and formative assessment of learners' language skills in modules 1 and 2; "out" data of module 1 were used as "in" data for module 2 .

Table 4. Entry and formative assessment of learners' language skills in module 1

\begin{tabular}{|c|c|c|c|c|c|c|}
\hline \multirow{3}{*}{ Grades } & \multicolumn{6}{|c|}{$\begin{array}{c}\text { Weeks 1 and 2 } \\
\text { module 1 - "Introducing oneself and others" }\end{array}$} \\
\cline { 2 - 7 } & $\begin{array}{c}\text { Scenario 1 } \\
\text { (23 teachers) }\end{array}$ & $\begin{array}{c}\text { Scenario 2 } \\
\text { (16 high school } \\
\text { students) }\end{array}$ & $\begin{array}{c}\text { Scenario 3 } \\
\text { (15 adults) }\end{array}$ \\
\cline { 2 - 7 } & \multicolumn{7}{|c|}{ Number of learners scoring the grades indicated } \\
\cline { 2 - 7 } In & Out & In & Out & In & Out \\
\hline $\begin{array}{c}\text { High } \\
\text { distinction }\end{array}$ & 4 & $5(+)$ & 2 & 2 & 1 & 1 \\
\hline Distinction & 3 & 3 & 2 & $4(+)$ & 2 & $3(+)$ \\
\hline Credit & 6 & $7(+)$ & 1 & $4(+)$ & 5 & $4(-)$ \\
\hline Pass & 7 & $8(+)$ & 8 & $5(-)$ & 6 & $7(+)$ \\
\hline Fail & 3 & $-(-)$ & 3 & $1(-)$ & 1 & $-(-)$ \\
\hline
\end{tabular}

$\mathrm{HD}=$ High Distinction $=85-100 \%, \mathrm{D}=$ Distinction $=75-84 \%, \mathrm{C}=$ Credit $=65-74 \%, \mathrm{P}=$ Pass $=$ $50-64 \%, \mathrm{~F}=$ Fail $=0-49 \%$ 
Table 5. Entry and formative assessment of learners' language skills in module 2

\begin{tabular}{|c|c|c|c|c|c|c|}
\hline \multirow{3}{*}{ Grades } & \multicolumn{5}{|c|}{$\begin{array}{c}\text { Weeks 3 to 6 (u-Learning) } \\
\text { module 2 - "Meeting people" }\end{array}$} \\
\cline { 2 - 7 } & $\begin{array}{c}\text { Scenario 1 } \\
\text { (23 teachers) }\end{array}$ & $\begin{array}{c}\text { Scenario 2 } \\
\text { (16 high school } \\
\text { students) }\end{array}$ & $\begin{array}{c}\text { Scenario 3 } \\
\text { (15 adults) }\end{array}$ \\
\cline { 2 - 7 } & \multicolumn{7}{|c|}{ Number of learners scoring the grades indicated } \\
\cline { 2 - 7 } In & Out & In & Out & In & Out \\
\hline $\begin{array}{c}\text { High } \\
\text { distinction }\end{array}$ & 5 & $9(+)$ & 2 & $3(+)$ & 1 & $2(+)$ \\
\hline Distinction & 3 & $7(+)$ & 4 & 4 & 3 & $5(+)$ \\
\hline Credit & 7 & $4(-)$ & 4 & $5(+)$ & 4 & 4 \\
\hline Pass & 8 & $3(-)$ & 5 & $4(-)$ & 7 & $4(-)$ \\
\hline Fail & - & - & 1 & $-(-)$ & - & - \\
\hline
\end{tabular}

Great importance had collaborative and cooperative work for the development of the four language skills and of effective learning (Agostinho, Lefoe, \& Hedberg, 1997). During the development of the u-Learning module, that lasted four weeks/12 hours, the learners carried out the activities described at pages 6 and 7 in pairs and groups of 3-4 for about a third of each class ( 2 hours), with an average of 8 growing friendly and effective discussions/interactions; for the rest (1 hour) students worked individually, according to their pace and preferences, and with online interactive and self-assessment activities, or as a class group (e.g., listen-and-repeat activities).

The last week of the three courses was dedicated to the final F2F language test and to a feedback survey about the impact of u-Learning through the integration of paperbased and digital learning material with QR code in English classes, on three different clusters of learners. The survey consisted of 8 multiple choice questions and open ended comments at the end (a five-point Likert scale - strongly agree, agree, neutral, disagree and strongly disagree - was used) aiming to highlight the overall impact on the participants, the difficulties arisen, the advantages of adopting u-Learning and the outcomes in terms of LLL. Results are shown in the "Outcomes and discussion" section.

\section{Outcomes and Discussion}

According to the data of the entry test, as Table 3 highlights, the mobile devices owned by the participants were 13 in scenario 1,15 in scenario 2 and 11 in scenario 3 , therefore 39 learners out of 54 took part to the experience of u-Learning. 18.7\% used PDAs or smartphones, $14.3 \%$ used ultra-mobile PCs and 67\% laptops (in particular adults of scenario $3-72.7 \%$-, who did not own ultra-mobile PCs). The group of participants of scenario 3, LLL adults, were the decisively most active in the completion of the activities proposed (an average of $90 \%$ more in comparison with the other clusters). The participants' preference in carrying out the tasks focussed on video comprehension (31.7\% completed the video "Hot sands" and $30 \%$ the video on giving directions) rather than on videos on grammar structures (16.1\% for video on "can/could"). 
The learners' overall perception appears to be extremely positive, despite some difficulties. All the participants judged the technical guidelines and support provided at the beginning as clear, handy and helpful; nevertheless, the connection slowness they experienced with their mobile devices while working with the web-based activities coded in QR code demotivated them (62\%) (in particular teenagers of scenario $2-86.6 \%$-, in comparison with adults of scenario $3-45.5 \%)$. Since none of the students was familiar with troubleshooting, they pointed out that carrying out the tasks anywhere had sometimes been difficult, frustrating and time-consuming (42.6\%) (in particular teenagers of scenario $2-62 \%$-, in comparison with adults of scenario $3-27.3 \%$ ), and that a high technological know-how is necessary in such learning experiences (23.1\%). Faster data transmission, therefore, is an issue to be tackled in a future u-Learning experience $(84.6 \%)$. A second set of difficulties for some of the participants arose in getting familiar $(27.9 \%)$ with and understanding $(33.2 \%)$ web-based authentic material promptly, as most of them $(64.8 \%$, i.e. $35.2 \%$ false beginners and $29.6 \%$ intermediate students - table 3$)$ were used to standard English in a classroom setting. However, they stated that technology was essential in giving them direct access to the English language and that eventually the use of authentic audio and video streams bettered their listening skills and provided them with a deeper understanding of English culture, much more than the textbook cds had done before. All the participants appreciated the challenge of being exposed to a richer and more demanding learning environment, a new (58.1\%) and very enjoyable $(62.1 \%)$ learning experience for them. Learners defined as challenging learning to learn with mobile devices and QR code, but definitely worth it for the know-how they have acquired. More self-discipline is necessary (30\%) (in particular according to adults of scenario $3-54.5 \%$ - in comparison with teachers of scenario $1-15.4 \%$ ) and impersonal learning could be an issue $(18.2 \%)$, but on the other hand in their opinion this u-Learning module was very flexible $(79.2 \%)$ and useful $(74 \%)$. In general, respondents strongly confirmed that learning with QR codes allows independence from time and place (93.3, against $43 \%$ recorded in the entry survey), personalised learning (84.4, against $24 \%$ of the entry survey) and flexible contents (86.7, against $26 \%$ of the entry survey). In particular all the teachers (scenario 1) and the adults (scenario 3) unanimously agreed on these three advantages, while teenagers (scenario 2) appeared less convinced $(80 \%$, $53.3 \%$ and $60 \%$, respectively). In the end, all the respondents affirmed that they would like to repeat this u-Learning experience with integrated paper-based and digital learning material through QR code because "it's an easy, fast and flexible way of learning", "it's an independent way to interact with the Internet jungle" and "it's been very very useful and "spendable"". Table 6 reports results in detail (in bold all the figures mentioned above).

Table 6. Results of the exit survey

\begin{tabular}{|l|r|r|r|r|}
\multicolumn{1}{|c|}{$\begin{array}{c}\text { Feedback } \\
\text { questions }\end{array}$} & $\begin{array}{c}\text { Scenario 1 } \\
\text { 23 Italian } \\
\text { teachers }\end{array}$ & $\begin{array}{c}\text { Scenario 2 } \\
\text { 16 Italian } \\
\text { students }\end{array}$ & $\begin{array}{c}\text { Scenario 3 } \\
\text { 15 Italian } \\
\text { adults }\end{array}$ & \multicolumn{1}{|c|}{$\begin{array}{c}\text { Average } \\
\text { results }\end{array}$} \\
\hline $\begin{array}{l}\text { 1. How would you define this QR } \\
\text { code+paper experience? }\end{array}$ & & & & \\
- New & $53.8 \%$ & $75 \%$ & $45.5 \%$ & $\mathbf{5 8 . 1 \%}$ \\
- Pleasant, amusing & $53.8 \%$ & $87 \%$ & $45.5 \%$ & $\mathbf{6 2 . 1 \%}$ \\
- Flexible & $84.6 \%$ & $62 \%$ & $90.9 \%$ & $\mathbf{7 9 . 2 \%}$ \\
- Interesting & $53.8 \%$ & $50 \%$ & $45.5 \%$ & $49.8 \%$ \\
- Useful \\
- Hard, tiring & $69.2 \%$ & $62 \%$ & $90.9 \%$ & $\mathbf{7 4 \%}$ \\
& $38.5 \%$ & $\mathbf{6 2 \%}$ & $\mathbf{2 7 . 3 \%}$ & $\mathbf{4 2 . 6 \%}$ \\
\hline
\end{tabular}




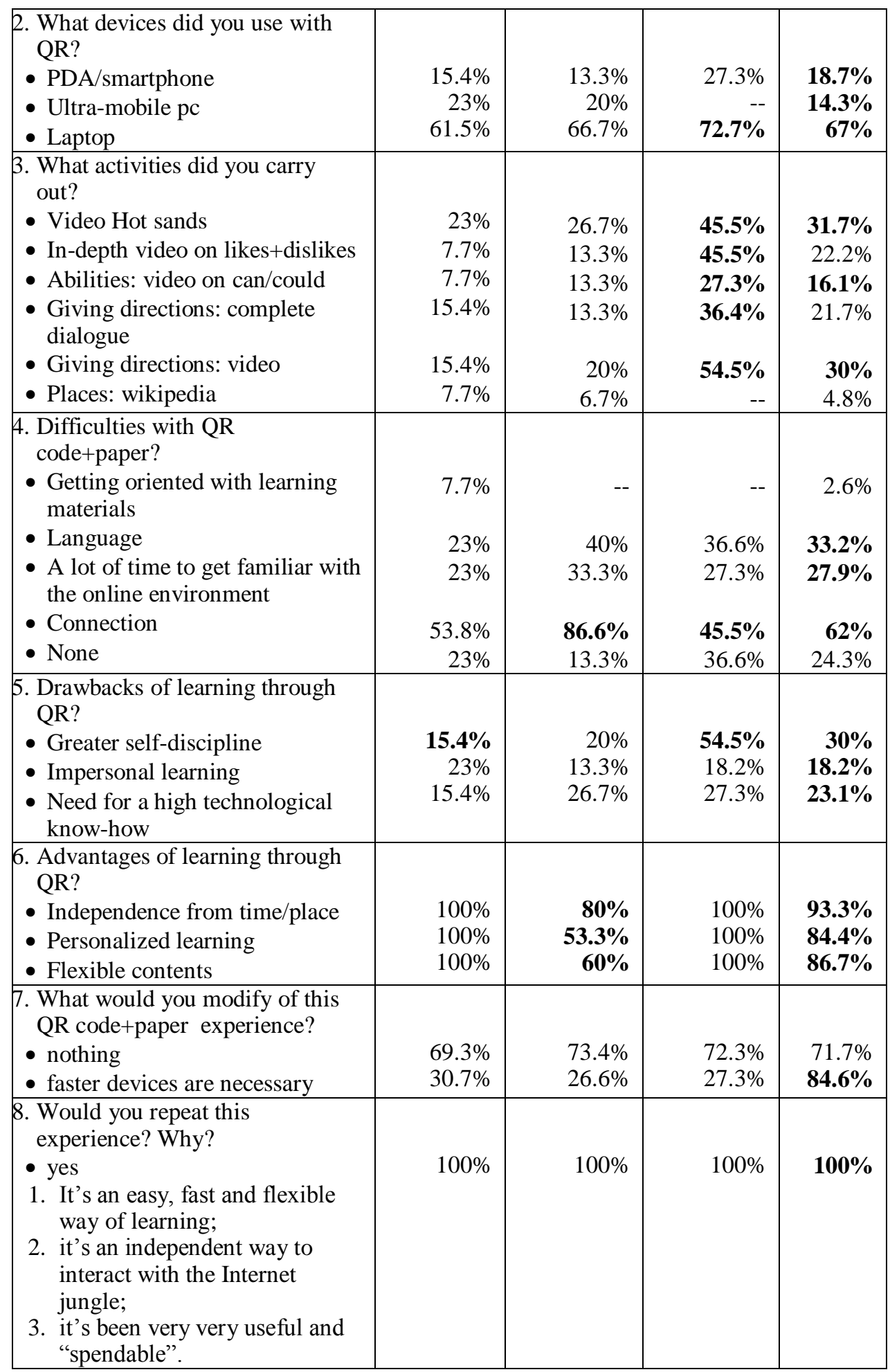


The results obtained from the integration of paper-based and digital learning material through QR code in the three different scenarios of EFL learning show an important positive impact on different aspects: the u-Learners' language skills, especially in listening and reading comprehension, management of ICT tools, satisfaction levels with the flexibility and personalisation of learning, as well as on the contents proposed and cross-curriculum objectives such as developing autonomy, building learning confidence, empowerment, a positive attitude and motivation towards learning a foreign language and about its culture, results which come to support the effectiveness of the model implemented.

The authors concur that $\mathrm{u}$-Learning is our future; it is increasingly recognised that $\mathrm{u}$-Learning, in its variety of forms, is shaping, and being shaped by, the way people live, work and learn. Still, u-Learning implementations are currently input dependent. The protracted methods of accessing stored information and services through the limited input functionalities of mobile phones, in particular, is time-consuming, frustrating and affects uptake of these mobile technologies. QR Codes can increase the impact of mobile devices, to enhance flexibility of provision and also to advance the personalisation of learning (Savarani \& Clayton, 2009).

However, the increasing use of QR codes creates challenges, like managing changes in approaches to learning. A technology-enhanced rather than technology-driven learning approach is crucial. Technology is too often considered as the only solution to a still partially rigid and remote learning system. The authors agree with this concept and believe in the implementation of instructional technology as a profitable way for learners to acquire a deeper sense of the language and culture they are studying, but the authors also concur that the adoption of the latest technology cannot, alone, carry any durable, regular and efficient improvement to teaching and learning. In the authors opinion a new technology can give rise to and enhance new learning environments and tools only if the divide between human actors, characterised by intentionality and values, and neutral technological devices is filled (actor-network theory). This is not new, but it seems it has not been acquired in the studies about u-Learning yet. In a future experience, the portability of mobile devices and paper textbooks, and the ubiquitous connection of paper-based learning with an online learning community (e.g., geo-social networks) may enhance the positive results obtained with this experience and offer a more effective learning environment, thanks to interaction and cooperation.

\section{Conclusions}

U-Learning is shaping, and being shaped by, the way we live, work and learn and uLearners, who are LLLearners, are becoming the protagonists of the learning scenario. The combination of traditional paper-based learning material with digital one in a ubiquitous learning environment may offer great innovation in the delivery of education, to foster a student-centred approach, and to accommodate the needs of ubiquitous learners' flexible lifestyles. Results of this study show that, despite some difficulties and some possible improvements, QR Codes can increase the impact of mobile devices, to enhance flexibility of provision and personalisation of learning. However, a technologyenhanced rather than technology-driven learning approach is crucial. 


\section{References}

1. Agostinho, S., Lefoe, G., \& Hedbeg, J. (1997). Online Collaboration and Problem Solving for Effective Learning: A Case Study of a Post Graduate University Course. Proceedings of AUSWEB97 The Third Australian World Wide Web Conference. Lismore: Southern Cross University.

2. Barr, R., \& Tagg, J. (1995). From Teaching to Learning: A New Paradigm for Undergraduate Education. Change Magazine, 2(12), 8-12. Retrieved January 11, 2008, from www.cic.uiuc.edu/resources/deo/paradigm.html

3. Bulu, S.T., \& Yildirim, Z. (2008). Communication Behaviors and Trust in Collaborative Online Teams. Educational Technology \& Society, 11 (1), 132-147.

4. Calvani, A. (2006). Reti, comunità e conoscenza. Costruire e gestire dinamiche collaborative. Trento: Erikson.

5. Chao, P.-Y., \& Chen, G.-D. (2009). Augmenting paper-based learning with mobile phones. Interacting with Computers, 21(3), 173-185.

6. Brown, J.S., Collins, A., \& Duguid, P. (1989). Situated Cognition and the Culture of Learning. Educational Researcher, 18(1), 32-42.

7. Chen, N.S., Teng, D.C.E., \& Lee, C.H. (2010). Augmenting Paper-based Reading Activities with Mobile Technology to Enhance Reading Comprehension. Proceedings of WMUTE2010, April 12-16 2010, Kaohsiung, Taiwan.

8. Chen, Y.S., Kao, T.C., Sheu, J.P., \& Chiang, C.Y. (2002). A Mobile ScaffoldingAid-Based Bird -Watching Learning System. Proceeding of International Workshop on Wireless and Mobile Technologies in Education, Los Alamitos: IEEE Computer Society, 15-22.

9. Curtis, M., Luchini, K., Bobrowsky, W., Quintana, C., \& Soloway, E. (2002). Handheld Use in K-12: A Descriptive Account. Proceeding of the International Workshop on Wireless and Mobile Technologies in Education, Los Alamitos: IEEE Computer Society, 32-30.

10. El-Bishouty, M.M., Ogata, H., \& Yano, Y. (2007). PERKAM: Personalized Knowledge Awareness Map for Computer Supported Ubiquitous Learning. Educational Technology \& Society, 10 (3), 122-134.

11. Ellis, R. (1999). Learning a second language through interaction. Amsterdam: John Benjamins Publishing Company.

12. Felder, R.M., \& Silverman, L.K. (1988). Learning and Teaching Styles in Engineering Education. Engineering Education, 78 (7), 674-681.

13. Jonassen, D.H., \& Land, S.M. (2000). Theoretical Foundations of Learning Environment. New Jersey: Lawrence Erlbaum Associates.

14. Keegan, D. (2004). The incorporation of mobile learning into mainstream education and training. Paper presented at The 18th Asian Association of Open Universities Annual Conference.

15. Kukulska-Hulme A., Sharples M., Milrad M., Arnedillo-Sánchez I., \& Vavoula G. (2009). Innovation in Mobile Learning: A European Perspective. International Journal of Mobile and Blended Learning, 1(1), 13-35.

16. Lai, W.-C., Chao, P.-Y. \& Chen, G.-D. (2007). The Interactive Multimedia Textbook: Using A Digital Pen to Support Learning for Computer Programming. Proceedings of ICALT, Seventh IEEE International Conference on Advanced Learning Technologies (ICALT 2007), pp.742-746. 
17. Lave, J., \& Wenger, E. (1991). Situated Learning. Legitimate Peripheral Participation. Cambridge, UK: Cambridge University Press.

18. Leone, S. (2008). The use of new technologies in advanced Italian classes. I. Olney, G. Lefoe, J. Mantei, \& J. Herrington (Eds.), Proceedings of the Second Emerging Technologies Conference 2008 (pp. 120-129). Wollongong (AUS): University of Wollongong.

19. Leone, S. (2010). F2F learning vs eLearning: the lifelong learner's point of view. Proceedings of INTED 2010, Valencia (Spain), 8th - 10th March 2010.

20. Leone, S., Leo, T., \& Chen, N.-S. (2010). An integrated model of synchronous cyber assessment and blended learning environment for foreign language learners. Computer Assisted Language Learning (to be published).

21. Levy, M. (1997). Computer-Assisted Language Learning: Context and Conceptualization. Oxford: Clarendon Paperbacks.

22. Nalder, J. (2008). The dawn of uLearning. Master thesis. Retrieved March 10, 2010 from http://www.scribd.com/doc/12398804/The-dawn-of-uLearning-JonathanNalder-Masters-thesis.

23. Nix, J. (2005). The development of mobile learning for smartphones. Proceedings of IADIS International Conference Applied Computing, Algarve, Portugal, February 22-25, 2005.

24. Nunan, D. (1991). Language teaching methodology. UK: Prentice Hall.

25. Ogata, H., \& Yano, Y. (2004). Context-Aware Support for Computer-Supported Ubiquitous Learning. Paper presented at the 2nd IEEE International Workshop on Wireless and Mobile Technologies in Education, March 23-25, 2004, JhongLi, Taiwan.

26. Piskurich, G.M. (2006). Rapid Instructional Design: Learning ID fast and right (2nd ed.). San Francisco, CA: Pfeiffer.

27. Ramsden, A. (2009.) The potential of QR Codes in Education. JISC Emerge Users \& Innovation Programme Meeting. Retrieved August 12, 2009, from http://www.slideshare.net/andyramsden/potential-qr-codes-education-emerge2009-presentation.

28. Riischoff, B., \& Ritter, M. (2001). Technology-enhanced Language Learning: Construction of Knowledge and Template-based Learning in the Foreign Language Classroom. Computer Assisted Language Learning (14/3-4), 219-232.

29. Saravani, S.A., \& Clayton, J.F. (2009). A conceptual model for the educational deployment of QR codes. Same places, different spaces. Proceedings Ascilite Auckland 2009.

30. Savery, J.R., \& Duffy, T.M. (1994). Problem based learning: an instructional model and its constructivist framework. Educational Technology, 8, 31-8.

31. Schank, C. (1995). What We Learn When We Learn by Doing. Technical Report No. 60. Northwestern University, Institute for Learning Sciences.

32. Varisco, B.M. (2002). Costruttivismo socio-culturale. Genesi filosofiche, sviluppi psico-pedagogici, applicazioni didattiche. Roma: Carocci.

33. von Glasersfeld, E. (1998). Il costruttivismo radicale. Una via per conoscere ed apprendere. Roma: Società Stampa Sportiva.

34. Vygotsky, L.S. (1986). Thought and Language. Cambridge, MA: MIT Press. 
35. Warschauer, M. (Ed.) (1996). Telecollaboration in foreign language learning. Honolulu, HI: University of Hawai'i Second Language Teaching and Curriculum Center.

36. Wasson, B. (2007). Design and Use of Collaborative Network Learning Scenarios: The DoCTA Experience. Educational Technology \& Society, 10 (4), 3-16. 